\title{
DETECTION OF MECA GENE IN METHICILLIN-RESISTANCE STAPHYLOCOCCUS AUREUS (MRSA) STRAINS ISOLATED FROM BEEF MEAT USING POLYMERASE CHAIN REACTION
}

\author{
GIHAN M.O. MOHAMMED ${ }^{1}$ and TAGHREED A. HAFEZ ${ }^{2}$ \\ ${ }^{1}$ Bacteriology Department, Port-Said Branch, Animal Health Research Institute \\ ${ }^{2}$ Food Hygiene Department, Port-Said Branch, Animal Health Research Institute
}

Received: 24 August 2016; Accepted: 29 September 2016

\begin{abstract}
A total of 60 random samples of meat were collected from different butchers shops at Port- Said city and subjected to bacteriological examination. The prevalence of Staph. aureus coagulase positive was $10(16.6 \%)$. The coagulase positive Staph. aureus isolates were tested for their susceptibility to methicillin/ Oxaciillin. $6(60 \%)$ of the isolates were resistant to methicillin/ Oxaciillin. Multidrug resistance of MRSA strains was observed. The maximum resistance was observed against Ampicillin and Chloramphenicol (100\%) while the least resistance was observed against Streptomycin (66.6\%) followed by Gentamicin and Trimethoprim + Sulphamethoxazole $(33.3 \%)$ and Erythromycin $(16.6 \%)$. The isolates were analyzed for the presence of the genes encoding resistance to methicillin (mecA) by using Polymerase chain reaction (PCR) which is a powerful and a rapid procedure for the detection of mecA gene in methicllin-resistance (MRSA) strains. Only 3 out of 6 isolates were found to carry the $m e c A$ gene amplified at $310 \mathrm{bp}$. The Staph. aureus found in meat directly affect the human health and can cause a public illness if the meat is used in the food industry. Examination of meat using convetional PCR is a useful technique for detection of $m e c A$ gene in Methicillin-resistance Staph. aureus (MRSA).
\end{abstract}

Keywords: Methicllin-resistance Staphylococcus aureus (MRSA) strains, meat, mecA gene, PCR.

\section{INTRODUCTION}

Staph. aureus is the most commonly isolated human bacterial pathogen and is an important cause of skin and soft tissue infections, endovascular infections, pneumonia, septic arthritis, endocarditis, osteomyelitis, foreign-body infections, and sepsis (McDougal et al., 2003). Methicillin-resistant Staph. aureus (MRSA) is considered one of the most common pathogens causing nosocomial infection (Shore and Coleman, 2013). MRSA strains are categorized into two families. The first family is known as the community-acquired MRSA (CAMRSA) strains and are associated with strains acquired in community settings and are expected to be sensitive for many antibiotics. The second family is the hospital-acquired MRSA strains which originate from hospital infections and are resistant to many antibiotics. Foodstuffs have been considered as sources of MRSA strains, therefore, surveying and surveillance activities for foodstuffs harboring MRSA strains is needed (Yamamoto et al., 2013).

Corresponding author: Dr. GIHAN M.O. MOHAMMED

E-mail address: dr.gehanomer@yahoo.com

Present address: Bacteriology Department, Port-Said Branch, Animal Health Research Institute
Meat has an important role in human nutrition as it is desirable foodstuff. It is important sources for protein, fat, essential amino acids, minerals, vitamins and other nutrients (Biesalski, 2005). Meat is rich in nutrients required for microorganisms growth so they are considered an ideal culture medium for growth of many organisms because of the high moisture, high percentage of nitrogenous compounds of various degree of complexity, plentiful supply of minerals, accessory growth factors and some fermentable carbohydrates (glycogen) of a favorable $\mathrm{pH}$ for most of enteric microorganisms. It may become contaminated from different sources, these sources may be originated from human handling, manipulation and/or the animal itself or from environmental contamination which includes: Air and water which are the most important sources, dirty floors, tables, equipment and knives (Marritto and Gravani, 2006). During slaughtering processes MRSA can be contaminated on carcasses, contributing to the contamination rates of MRSA on meats in butchers shops, Therefore, meat acts as the vehicle in transmission of MRSA to the butchers and consumers (Boost et al., 2012 and 2013). The surveillance of MRSA in meat was thought to be important. Several studies of MRSA in meat have been documented in various countries (Jones et al., 
2002; Kitai et al., 2005; Van Loo et al., 2007 and Weese et al., 2010).

The use of antibiotics and other antimicrobial agents throughout the food chain contributes to the emergence of resistant bacteria that can be passed directly to humans after ingestion (Ruzauskas et al., 2010). Antibiotic resistance bacteria can cause serious disease and is an important public health problem, antibiotic resistance bacteria can be prevented by minimizing unnecessary prescribing and overprescribing of antibiotics, correct use of prescribed antibiotics, good hygiene and infection control (Kumarasamy et al., 2010).

Treatment of infections caused by Staph. aureus has been further complicated by antimicrobial resistance in the bacteria, particularly methicillin-resistant Staph. aureus (MRSA) Naimi et al. (2003). Methicillin-resistant Staph. aureus (MRSA) isolates are resistant to all available penicillins and other Blactam antimicrobial drugs. (Hennekinne et al., 2012). Resistance to methicillin is mediated through the mec operon which is a part of the staphylococcal cassette chromosome mec (SCCmec) (El Karamany et al., 2013). The mecA gene codes for an altered penicillinbinding protein, PBP2a, which has a lower affinity for binding $\beta$-lactam antibiotics (Mostafa, 2013). Thus, we aimed to investigate the prevalence of coagulase Positive Staph. aureus and detection of MRSA strains in meat collected from some Port- Said city butchers shops and detection of their antibiotic susceptibility profiles and presence of antibiotic resistant gene (mecA) by conventional PCR.

\section{MATERIALS AND METHODS}

1- Sampling: A total of 60 samples of meat were collected from different butchers shops at PortSaid city. Collected samples were double-bagged upon purchase to avoid cross-contamination and, transferred in an ice box and transported to the laboratory as soon as possible to be examined within 24 hours.

\section{2- Bacteriological examination:}

2-1 Isolation and Identification of Staphylococcus aureus: According to Singh and Prakash (2008) with slight modification. Enrichment was carried out in Peptone Water (PW) enrichment broth (Himedia, India), 10 gram of sample was homogenized with $90 \mathrm{ml}$ sterile enrichment broth peptone water and enriched for $24 \mathrm{hrs}$ at $37{ }^{\circ} \mathrm{C}$. The selective medium used for isolation of Staph. aureus was Baird Parker Agar (BPA) (Himedia, India). A loopful of inoculum from enrichment broth was streaked onto BP agar and incubated aerobically for 48 hours at $37^{\circ} \mathrm{C}$. Characteristic appearance of jet black colonies surrounded by a white halo was considered to be presumptive Staph. aureus. The pure colonies were streaked onto Nutrient agar slop (Himedia, India) and incubated aerobically for 24 hours at $37^{\circ} \mathrm{C}$ for further identification.

2-2 Morphological characteristics: Smear were prepared from the isolated colonies and stained with Gram's stain. The stained smear revealed Gram positive, spherical cells arranged in irregular clusters resembling to bunch of grapes according to Quinn et al. (2002).

2-3 Biochemical examination: The biochemical tests were performed to confirm Staph. aureus using Catalase test, Coagulase test, DNase test, Acetoin production, Oxidase test and D-mannitol fermentation according to Thaker et al. (2013).

\section{3- Methicillin (oxacillin) susceptibility}

Methicillin /Oxacillin sensitivity was determined by an agar screen test performed according to the recommendations of the National Committee for Clinical Laboratory Standards (NCCLS, 2004) with Mueller-Hinton agar (Difco) containing 4\% $\mathrm{NaCl}$ and $2 \mu \mathrm{g}$ of oxacillin (Sigma, St. Louis, Mo.) per ml. The strains were reported as sensitive, or resistant, to Methicillin /Oxacillin with inhibition zone diameter equal or more than $13 \mathrm{~mm}$ and less than or equal to $10 \mathrm{~mm}$ respectively. Disk diffusion testing was performed as recommended by the National Committee for Clinical Laboratory Standards NCCCL (2004); briefly, a broth culture suspension of the isolate to be tested was prepared in trypticase soy broth and turbidity adjusted to a 0.5 McFarland standard. The zone sizes were read after 24 hours of incubation in ambient air at $35^{\circ} \mathrm{C}$. The MRSA isolates were tested for susceptibility to the following additional antibiotics: Ampicillin $(10 \mu \mathrm{g})$, Chloramphenicol $(30 \mu \mathrm{g})$, Erythromycin $(15 \mu \mathrm{g})$, Gentamicin $(10 \mu \mathrm{g})$,

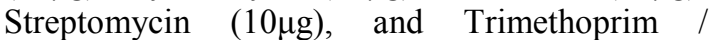
Sulphamethoxazole $(1.25+23.75)$.

4- Molecular detection of mecA gene in Methicillinresistance Staph. aureus (MRSA) strains:

4.1- DNA extraction: DNA extraction from the isolated strains was performed using the QIAamp DNA Mini kit (Qiagen, Germany, GmbH) with modifications from the manufacturer's recommendations. Briefly, $200 \mu \mathrm{l}$ of the sample suspension was incubated with $10 \mu \mathrm{l}$ of proteinase $\mathrm{K}$ and $200 \mu \mathrm{l}$ of lysis buffer at $56^{\circ} \mathrm{C}$ for $10 \mathrm{~min}$. Then $200 \mu \mathrm{l}$ of $100 \%$ ethanol was added to the lysate. The sample was then washed and centrifuged following the manufacturer's recommendations. Nucleic acid was eluted with $100 \mu 1$ of elution buffer provided in the kit.

4.2- Oligonucleotide Primer Staph. aureus: Primers used were supplied from Metabion (Germany) are listed in table (1). 
Table 1: Primer sequence, target gene, amplicon size and cycling conditions of Staph. aureus MRSA strain.

\begin{tabular}{|c|c|c|c|c|c|c|c|c|}
\hline \multirow{2}{*}{$\begin{array}{l}\text { Target } \\
\text { gene }\end{array}$} & \multirow{2}{*}{ Primers sequences } & \multirow{2}{*}{$\begin{array}{c}\text { Amplified } \\
\text { segment } \\
\text { (bp) }\end{array}$} & \multirow{2}{*}{$\begin{array}{c}\text { Primary } \\
\text { Denaturation }\end{array}$} & \multicolumn{3}{|c|}{ Amplification ( 35 cycles) } & \multirow{2}{*}{$\begin{array}{c}\text { Final } \\
\text { extension }\end{array}$} & \multirow{2}{*}{ Reference } \\
\hline & & & & $\begin{array}{c}\text { Secondary } \\
\text { denaturation }\end{array}$ & Annealing & Extension & & \\
\hline mecA & GTA GAA ATG ACT & \multirow[b]{3}{*}{310} & \multirow[b]{3}{*}{$\begin{array}{l}94^{\circ} \mathrm{C} \\
5 \mathrm{~min} .\end{array}$} & \multirow[b]{3}{*}{$\begin{array}{c}94^{\circ} \mathrm{C} \\
45 \mathrm{sec} .\end{array}$} & \multirow[b]{3}{*}{$\begin{array}{c}50^{\circ} \mathrm{C} \\
45 \text { sec. }\end{array}$} & \multirow[b]{3}{*}{$\begin{aligned} 72^{\circ} \mathrm{C} \\
45 \mathrm{sec}\end{aligned}$} & \multirow[b]{3}{*}{$\begin{array}{c}72^{\circ} \mathrm{C} \\
10 \mathrm{~min}\end{array}$} & \multirow[b]{3}{*}{$\begin{array}{c}\text { McClur } \\
\text { e et al.., } \\
(2006)\end{array}$} \\
\hline $\mathbf{F}$ & GAA CGT CCG ATA A & & & & & & & \\
\hline $\mathbf{R}$ & $\begin{array}{c}\text { CCA ATT CCA CAT } \\
\text { TGT TTC GGT CTA A }\end{array}$ & & & & & & & \\
\hline
\end{tabular}

4.3- PCR amplification: Primers were utilized in a 25- $\mu$ l reaction containing $12.5 \mu \mathrm{l}$ of Emerald Amp Max PCR Master Mix (Takara, Japan), $1 \mu 1$ of each primer of 20 pmol concentrations, $4.5 \mu \mathrm{l}$ of water, and $6 \mu 1$ of DNA template. The reaction was performed in an applied biosystem 2720 thermal cycler.

4.4- Analysis of the PCR Products: The products of PCR were separated by electrophoresis on $1.5 \%$ agarose gel (Applichem, Germany, $\mathrm{GmbH}$ ) in $1 \mathrm{x}$ TBE buffer at room temperature using gradients of $5 \mathrm{~V} / \mathrm{cm}$. For gel analysis, $20 \mu \mathrm{l}$ of the uniplex PCR products were loaded in each gel slot. A 100 bp DNA ladder and a 100 bp plus DNA Ladder (Qiagen, Germany, $\mathrm{GmbH}$ ) were used to determine the fragment sizes. The gel was photographed by a gel documentation system (Alpha Innotech, Biometra) and the data was analyzed through computer software.

\section{RESULTS}

Table 2: Incidence of coagulase positive Staph. aureus in examined meat samples.

\begin{tabular}{cccc}
\hline \multirow{2}{*}{ sample } & \multirow{2}{*}{ No. } & \multicolumn{2}{c}{ Coagulase Positive Staph. aureus } \\
\cline { 3 - 4 } & & No. & $\%$ \\
\hline Meat & 60 & 10 & $16.6 \%$ \\
\hline
\end{tabular}

Table 3: Methicillin (oxacillin) susceptibility of coagulase positive Staph. aureus $(\mathrm{n}=10)$.

\begin{tabular}{ccccc}
\hline \multicolumn{2}{c}{ Sensitive } & \multicolumn{2}{c}{ Resistant } \\
\hline No. & $\%$ & No. & $\%$ \\
\hline 4 & & $40 \%$ & 6 & $60 \%$ \\
\hline
\end{tabular}

Table 4: Susiptability of MRSA to other antimicrobials $(n=6)$.

\begin{tabular}{cccc}
\hline Antimicrobial & Disc potency & No. & \% \\
\hline Ampicillin (AMP) & $(30 \mathrm{mg})$ & 6 & $100 \%$ \\
\hline Chloramphenicol (C) & $(30 \mu \mathrm{g})$ & 6 & $100 \%$ \\
\hline Erythromycin (E) & $(15 \mathrm{mg})$ & 1 & $16.6 \%$ \\
\hline Gentamicin (CN) & $(10 \mathrm{mg})$ & 2 & $33.3 \%$ \\
\hline Streptomycin (S) & $(10 \mu \mathrm{g})$ & 4 & $66.6 \%$ \\
\hline Trimethoprim + Sulphamethoxazole (SXT) & $(1.25+23.75)$ & 2 & $33.3 \%$ \\
\hline
\end{tabular}

Table 5: illustrating the results of PCR for the detection of mecA genes.

\begin{tabular}{ccccccccccc}
\hline Staph. aureus strain & 1 & 2 & 3 & 4 & 5 & 6 & Total & $\%$ \\
\hline mecA gene & + & + & + & - & - & - & $3 / 6$ & 50 \\
\hline
\end{tabular}

+ : Positive for $m e c A$ gene.

-: Negative for $m e c A$ gene 


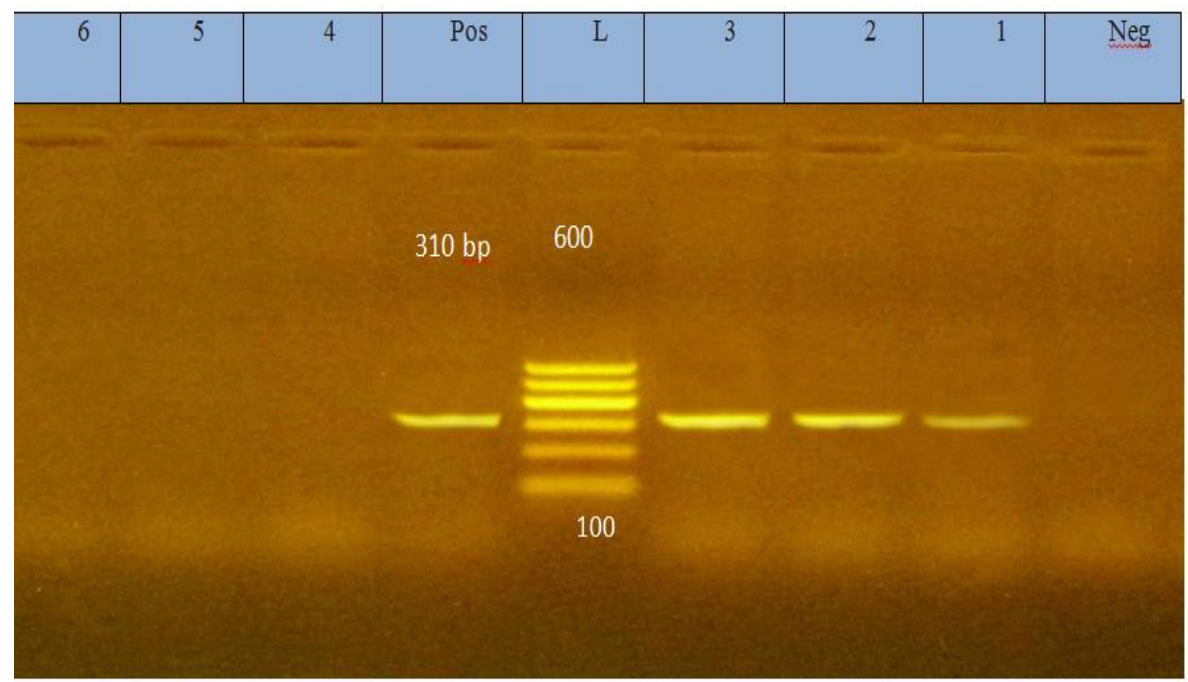

Fig. (1): Showing Agarose gel electrophoresis of PCR products after amplification of: $\boldsymbol{m e c \boldsymbol { A }}$ gene. MWMmolecular weight marker (100 - 600 bp DNA ladder), + control (Positive, Negative) + different strains of Staph. aureus (mecA gene products at $310 \mathrm{bp}$ ).

\section{DISCUSSION}

Meat is an important vector for the transfer of antibiotic resistances from animals to humans, and antimicrobial resistance has always been a major concern for nosocomial infections in hospital environments. Such transfer can occur in three ways: by means of antibiotic residues in food, through the transfer of resistant food borne pathogens, or through the ingestion of resistant parts of the original food micro flora and resistance transfer to pathogenic microorganisms (Mayrhofer et al., 2004).

Staph. aureus is considered to be one of causes of food borne illnesses. Meat is often contaminated with strains of this bacterium, that may occur directly from infected food-producing animals or may result from poor hygiene during transportation, and hygienic level during slaughter also, during evisceration contamination may come from intestinal contents as well as from water during rinsing and washing of carcasses (Marritto and Gravani, 2006). In the present study $10(16.6 \%)$ isolates of coagulase positive Staph. aureus could be detected from the 60 examined meat samples (Table 2). Nearly to findings were obtained by (Goja et al., 2013), who isolated Staph. aureus 7 $(12 \%)$ from meat, while various studies done by Aseel et al. (2010) and Ezzat et al. (2014) showed lower prevalence of Staph. aureus $(5.55 \%)$ and (10\%), respectively. Another studies showed higher prevalence of Staph. aureus was obtained by (Mansour and Basha 2009; Andrew et al., 2011 and Sajith et al., 2012) in a percentage of (20\%),(37\%) and $(40.2 \%)$, respectively from meat. Meat can be contaminated at several points throughout the processing operations. Moreover, retail cuts could result in greater microbial load owing to large amount of exposed surface area, more readily available water, nutrient and greater oxygen (Nørrung et al., 2009). The higher incidence of Staph. aureus may be due to the unsanitary condition of the butcher, absence of the health services in butcheries shops, unhygienic manner, processing, transportation and storage.

Methicillin-resistant Staphylococcus aureus (MRSA) is a major human pathogen, causing severe morbidity and mortality worldwide both in hospitals and the community. In our study the susiptability of coagulase positive Staph. aureus strains isolated from examined meat to Methicillin / Oxaciillin was shown in Table (3), out of 10 coagulase positive Staph. aureus strains 6 isolates were found to be resistant (60\%). Similar findings were obtained by (Jackson et al., 2013). While higher incidences were observed by (de Boer et al., 2009; Ogata et al., 2012; Nnachi et al., 2014 and Food Microbiology and Safety, 2015).

Multi-drug resistance (MDR) refers to a condition enabling pathogenic organisms to resist distinct antibiotics of a wide variety of structure and function targeted at eradicating the organism. Multidrug resistance, defined as intermediate or complete resistance to 3 or more antimicrobial classes. In our study the confirmed MRSA isolates were examined for its multidrug resistance ability to different antimicrobials and the study revealed that $6(100 \%)$ of the isolates were resistant to Ampicillin and Chloramphenicol, 4(66.6\%) were resistant to Streptomycin, 3(33.3\%) were resistant to Gentamicin and trimethoprim- sulphamethoxazole and 1(16.6\%) was resistant to Erythromycin (table 4). Frequently, MRSA isolates are also resistant to other antimicrobial classes (Weese, 2010 and Borah et al., 2016). Strains of Staph. aureus have been observed to 
show resistance against multiple antimicrobials (Kumar et al., 2010 and Khalifa et al., 2014). A comparison of the antibiotic resistance pattern with that reported by Abass, (2014), revealed much similarity, who reported that Staph. aureus from meat were resistant to Chloramphenicol, on the other hand they were sensitive to trimethoprimsulphamethoxazole, erythromycin, while she disagree in susceptibility of strains Streptomycin.

The prevalence of antimicrobial drug resistance among food-borne pathogens is increased due to its use in human therapy and animal farming for therapeutic and prophylactic purposes. Multidrug resistant Staph. aureus are frequently isolated from food sources. Such strain are more dangerous and of great food safety concern (Wise, 2007 and Van et al., 2012).

The threat of antibiotic-resistant bacteria has initiated studies on the nature of genes encoding resistance and the mechanism by which these genes spread and evolve. The isolated MRSA strains were examined by conventional PCR for the presence of resistant gene (mecA). The PCR assay confirmed the presence of $m e c A$ gene in 3 strains $(50 \%)$ at 310 bp Table (5) and Figures (1), which is agree with (Riffon et al., 2001; John, 2003; Sajith Khan et al., 2012 and Kamal et al., 2013) who found that PCR assay was rapid and accurate procedure for the detection of MRSA strains as compared to the conventional methods since the reporting time is less and can help efficiently in infection management. In a study performed by Podkowik et al. (2012) the authors observed prevalence mecA genes conferring resistance to Oxacillin, Penicillin, belonging to twelve staphylococcal isolates obtained from ready-to-eat porcine, bovine, and chicken products.

\section{Conclusion and Recommendations}

We can conclude from the obtained results that meat could be a source of resistant bacteria, which may create a health risk for consumers. Some bacteria that are capable of causing serious disease are becoming resistant to most commonly available antibiotics. Moreover, the microbiological safety of food has to be guaranteed in order to prevent the transmission of pathogen or opportunist microorganisms to the consumer. PCR assay was found to be a rapid and accurate procedure for the confirmation identification and determination of the mecA genes of Staph. aureus by conventional methods which requires a minimum of two-day period, since the time taken for PCR assay is much less a few hours, prompt treatment can be initiated in view of medical and less economic costs. Therefore, The conventional PCR assay can be used as an accurate, safe, and fast technique for the confirmation of Staph. aureus and its antibiotic resistance genes in meat samples.

\section{REFERENCES}

Abass, M.M.S. (2014): Molecular characterization of Staphylococcus aureus isolated from meat, milk and their products. M.V. Sc. Thesis, (Bacteriology, Immunology and Mycology) Faculty of Veterinary Medicine. Suez Canal University.

Andrew, E.W.; Tania, C.; Jordan, B.; Cindy, M.L.; Lindsey, W.; Kimberly, P.; Jeffrey, T.F.; Jolene, B.; Elizabeth, M.D.; David, M.E.; Paul, S.K. and Lance, B.P. (2011): MultidrugResistant Staphylococcus aureus in US meat and poultry. BRIEF REPORT. Clinical Infectious Diseases Advance Access, 52(10): $1-4$.

Aseel, M.H.; Maysoon, S.A. and Waffa, A.A. (2010): The isolation and identification of the important pathogenic bacteria from fresh meat. The Iraq J. for Vet. Med., 23 (1): 44-50.

Biesalski, H.K. (2005): Meat as a component of a healthy diet. Are there any risks or benefits if meat is avoided in the diet. Meat Science; 70: 509-524.

Boost, M.; Ho, J.; Guardabassi, L. and O'Donoghue, M. (2012): Colonization of buchers with livestock-associated methicillin-resistant Staphylococcus aureus. Zoonoses Public Health.

Boost, M.V.; Wong, A.; Ho, J. and O'Donoghue, M. (2013): Isolation of methicillin-resistant Staphylococcus aureus (MRSA) from retail meats in Hong Kong. Food-borne Pathogens and Disease 10: 1-6.

Borah, D.; Singh, V.; Gogoi, B.; Hazarika, M. and Rahman, A. (2016): Prevalence of Multidrug Resistant (MDR) Novel Enterococcus faecium Strain VDR03 in Broiler Chicken Meat Samples Collected from Dibrugarh Town, Assam (India). Journal of Microbiology, 11: 126-132.

de Boer, E.; Zwartkruis-Nahuis, J.T.; Wit, B.; Huijsdens, X.W.; de Neeling, A.J.; Bosch, T.; van Oosterom, R.A.; Vila, A. and Heuvelink, A.E. (2009): Prevalence of methicillin-resistant Staphylococcus aureus in meat. Inter. J. Food Microbiol., 134(1-2): 5256.

El Karamany, I.M.; Ibrahim, Y.M.; Abouwarda, A.M.; Essam, T.M. and Amin, M.A. (2013): Detection of high levels of methicillin and multi-drug resistance among clinical isolates of Staphylococcus aureus. African Journal of Microbiology Research 7: 1598-1604.

Ezzat, M.; Shabana, I.I.; Riad, E.M. and Sarah, M.A. (2014): Molecular characterization of Staphylococcus auerus isolated from meat, milk and their products. Suez Canal Veterinary Medicine J., 19(1): 137-152.

Food Microbiology and Safety (2015): MethicillinResistant Staphylococcus aureus in raw meats 
and prepared foods in public hospitals in Salvador, Bahia, Brazil. Journal of Food Science, 80(1): 147-150.

Goja, A.M.; Ahmed, T.A.A.; Saeed, S.A.M. and Dirar, H.A. (2013): Isolation and Identification of Staphylococcus spp. in Fresh Beef. Pakistan Journal of Nutrition 12 (2): 114-120.

Hennekinne, J.A.; De Buyser, M.L. and Dragacci, S. (2012): Staphylococcus aureus and its food poisoning toxins: characterization and outbreak investigation. FEMS Microbiol. Rev. 36: $815-836$.

Jackson, C.R.; Davis, J.A. and Barrett, J.B. (2013): Prevalence and Characterization of Methicillin-Resistant Staphylococcus aureus isolates from retail meat and humans in Georgia. J. Clin. Microbiol., 51(4): 11991207.

Jones, T.F.; Kellum, M.E.; Porter, S.S.; Bell, M. and Schaffner, W. (2002): An outbreak of community-acquired food-borne illness caused by methicillin-resistant Staphylococcus aureus. Emerging Infectious Diseases 8: 8284.

John, H.L. (2003): Methicillin (Oxacillin)-Resistant Staphylococcus aureus strains isolated from major food animals and their potential transmission to humans. Appl. Environ. Microbiol., 69(11): 6489-6494.

Kamal, M.R.; Mohamed, A.B. and Salah, F.A. (2013): MRSA detection in raw milk, some dairy products and hands of dairy workers in Egypt, a mini-survey. Food Control,33(1): 49-53.

Khalifa, S.M.; Abdel-Rhman, H.S.H.; Abd El Galil, K.H.; Habib, E. and Barwa, R. (2014): Occurrence and Characterization of Staphylococcus aureus in Meat and Meat Products Marketed in Mansoura, Egypt. Egyptian Journal of Medical Microbiology, 23(3): 47-56.

Kitai, S.; Shimizu, A.; Kawano, J.; Sato, E.; Nakano, C.; Uji, T. and Kitagawa, H. (2005): Characterization of methicillin-resistant Staphylococcus aureus isolated from retail raw chicken meat in Japan. J. Vet. Sci. 67: 107110.

Kumar, R.; Yadav, B.R. and Singh, R.S. (2010): Genetic determinants of antibiotic resistance in Staphylococcus aureus isolates from milk of mastitic crossbred cattle. Current Microbiology, 60(5): 379-386.

Kumarasamy, K.K.; Toleman, M.A.; Walsh, TR.; Bagaria, J. Butt, F. and Balakrishnan, R. (2010): Emergence of a new antibiotic resistance mechanism in India, Pakistan, and the UK: A molecular, biological, and epidemiological study. Lancet Infect Dis., 10: 597-602.

Mansour, A.F.A. and Basha, O.A.M. (2009): Hygienic status of imported frozen beef in
Alexandria markets. Assiut Vet. J., 55 (121): 162-171.

Marriott, N.G. and Gravani, R.B. (2006): Principles of food sanitation. $5^{\text {th }}$ Ed. Springer, Heidelberg.

Mayrhofer, S.; Paulsen, P.; Smulders, F.J. and Hilbert, F. (2004): Antimicrobial resistance profile of five major food-borne pathogens isolated from beef, pork and poultry. International Journal of Food Microbiology, 97: 23-29.

McClure, J.A.; Conly, J.M.; Lau, V.; Elsayed, S.; Louie, T.; Hutchins, W. and Zhang, K. (2006): Novel multiplex PCR assay for detection of the staphylococcal virulence marker PantonValentine leukocidin genes and simultaneous discrimination of methicillin-susceptible from -resistant staphylococci. J. Clin. Microbiol., 44: 1141-114.

McDougal, L.K.; Steward, C.D.; Killgore, G.E.; Chaitram, J.M.; McAllister, S.K. and Tenover, F.C. (2003): Pulsed-field gel electrophoresis typing of oxacillin-resistant Staphylococcus aureus isolates from the United States: establishing a national database. J. Clin. Microbiol.; 41(11): 5113-5120.

Mostafa, S.I. (2013): Molecular typing of methicillin resistant Staphylococcus aureus by spa gene polymorphism. African Journal of Microbiology Research 7: 755-759.

Naimi, T.S.; LeDell, K.H.; Como-Sabetti, K.; Borchardt, S.M.; Boxrud, D.J. Etienne, J.; Johnson, S.K.; Vandenesch, F.; Fridkin, S.; O'Boyle, C.; Danila, R.N. and Lynfield, R. (2003): Comparison of community- and health care-associated methicillin-resistant Staphylococcus aureus infection. JAMA 290: 2976-2984.

Nnachi, A.U.; Emele, F.E.; Ukaegbu, C.O.; Agah, M.V.; Udu-Ibiam, O.E.; Chukwu, O.S. and Agwu, M. (2014): Prevalence of methicillinresistant Staphylococcus aureus (MRSA) in raw meat and meat handlers in Onitsha, Nigeria. European Journal of Preventive Medicine, 2(1): 9-15.

National Committee for Clinical Laboratory Standards (NCCLS) (2004): Performance Standards for Antimicrobial Disk and Dilution Susceptibility Tests for Bacteria Isolated from Animals; 2nd ed. NCCLS M100-S14. Clinical Laboratory Standards Institute (formerly NCCLS), Wayne, PA.

Norrung, B.; Andersen, J.K. and Buncic, S. (2009): Main Concerns of Pathogenic Microorganisms in Meat Safety of Meat and Processed Meat. F. Toldrá, ed. (Springer NewYork): 3-29.

Ogata, K.; Narimatsu, H.; Suzuki, M.; Higuchi, W.; Yamamoto, T. and Taniguchi, H. (2012): Commercially distributed meat as a potential vehicle for community-acquired Methicillin- 
Resistant Staphylococcus aureus. Appl. Environ. Microbiol., 78 (8): 2797-2802.

Podkowik, M.; Bystroń, J. and Bania, J. (2012): Prevalence of antibiotic resistance genes in staphylococci isolated from ready-to-eat meat products. Poland J. Veterinary Science 15(2): 233-7.

Quinn, P.; Markey, B.; Carter, M.; Donelly, W. and Leonard, F. (2002): Veterinary microbiology, Microbial Disease. Black Well Science: 26-36.

Riffon, R.; Sayasisth, K.; Khalil, H.; Dubereuil, P.; Drolletr, M. and Lagace, J. (2001): Development of a rapid and sensitive test for identification of major pathogens in bovine mastitis by PCR. J. Clin. Microbiol. 39(7): 2584-2589.

Ruzauskas, M.; Suziedeliene, E.; Siugzdiniene, R.; Seputiene, V. and Povilonis J. (2010): Antimicrobial resistance of Enterococcus spp. spread in poultry products in Lithuania. Journal of Food Safety, 30: 902-915.

Sajith, K.A.; Preetha, J.S.; Lakshmi, S.Y.; Anandi, C. and Ramesh, R. (2012): Detection of mecA genes of Methicillin-Resistant Staphylococcus aureus by Polymerase Chain Reaction. International Journal of Health and Rehabilitation Sciences 1(2): 64-68.

Shore, A.C. and Coleman, D.C. (2013): Staphylococcal cassette chromosome mec: Recent advances and new insights. Int. J. Med. Microbiol. 303: 350-359.

Singh, P. and Prakash, A. (2008): Isolation of Escherichia coli, Staphylococcus aureus and Listeria monocytogenes from milk products sold under market conditions at Agra Region. Acta Agri. Slov., 92(1): 83-88.

Thaker, H.C.; Brahmbhatt, M.N. and Nayak, J.B. (2013): Isolation and identification of Staphylococcus aureus from milk and milk products and their drug resistance patterns in Anand, Gujarat. Vet. World, 6 (1): 10-13.

Van, T.T.H.; Nguyen, H.N.K.; Smooker, P.M. and Coloe, P.J. (2012): The antibiotic resistance characteristics of non-typhoidal Salmonella enteric isolated from food producing animals, retail meat and humans in South East Asia. Int. J. Food Microbiol.; 154: 98-106.

Van Loo, I.; Huijsdens, X. and Tiemersma, E. (2007): Emergence of methicillin resistant Staphylococcus aureus of animal origin in humans. Emerg Infect Dis; 13:1834-9.

Weese, J.S. (2010): Methicillin-Resistant Staphylococcus aureus in Animals. Institute of Laboratory Animal Research J. 51(3): 236244.

Weese, J.S.; Avery, B.P. and Reid-Smith, R.J. (2010): Detection and quantification of methicillinresistant Staphylococcus aureus (MRSA) clones in retail meat products. Letters in Applied Microbiology 51, 338-342.

Wise, R.E. (2007): Combating antimicrobial resistance: the role of the specialist advisory committee on antimicrobial resistance. J. Antimicrob. Chemother., 60 (1): 15-17.

Yamamoto, T.; Hung, W.C.; Takano, T. and Nishiyama, A. (2013): Genetic nature and virulence of community-associated methicillin-resistant Staphylococcus aureus. Biomedicine; 3(1): 2-18.

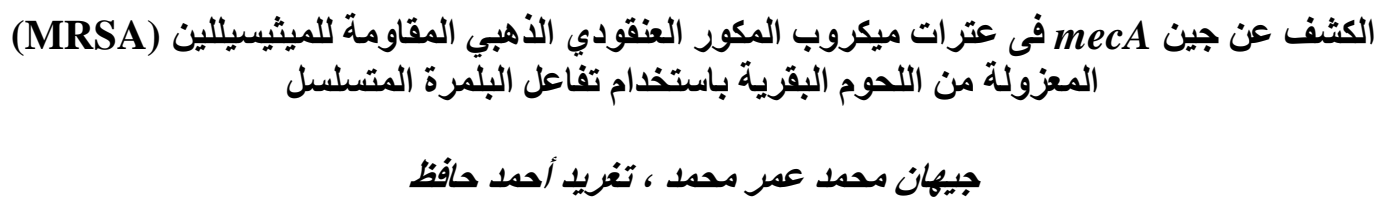

Email: dr.gehanomer@yahoo.com_Assiut University web-site: www.aun.edu.eg

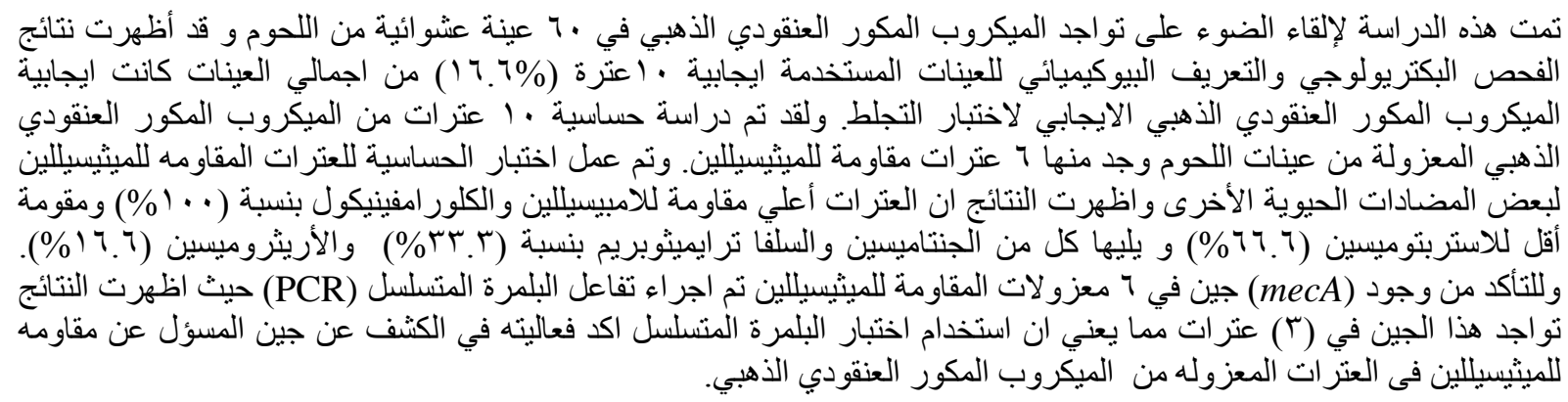

